\section{JURNAL ABDIMAS

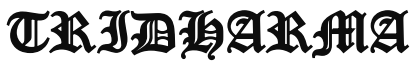 \\ AHA}

\title{
PENINGKATAN KAPASITAS PENJUALAN DAN PRODUKSI UMKM JAMU HERBAL ASRIFOOD, CARANGWULUNG, WONOSALAM, JOMBANG, JAWA TIMUR
}

\author{
Diah Krisnaningsih,Ruslianor Maika, Eka Vebrly Maretha, Nur Iza Faiza \\ Dosen Dan Mahasiswa Universitas Muhammadiyah Sidoarjo \\ Email : diah.krisnaningsih@umsida.ac.id,mr.maika@umsida.ac.id, \\ ekavebry127@gmail.com, izafaiza82@gmail.com \\ ABSTRAK
}

Isu utama pengabdian masyarakat saat ini adalah penggunaan digital marketing untuk peningkatn kapasitas penjualan dan produksi UMKM Jamu Herbal Asrifood, Carangwulung, Wonosalam Jombang, Jawa Timur karena belum optimalnya sistem pemasaran yang dimiliki UMKM terutama bidang digital marketing Sistem pemasaran yang dijalankan selama ini dengan sistem konsinyasi di beberapa toko oleh-oleh kota Jombang dan e commerce sehingga penjualan kurang maksimal.

Permasalahan lain yang dihadapi UMKM Jamu Herbal Asrifood, Carangwulung, Wonosalam Jombang, Jawa Timur ini adalah kapasitas produksi jamu herbal yang tidak maksimal karena kendala tidak memiliki mesin pengolah tepung atau penggiling sendiri dan selama ini meminjam dari tetangga. Hal tersebut pasti mengakibatkan proses produksi yang terhmbat dan tidak maksimal baik dari segi waktu, tenaga, dan biaya. Hasil pengabdian kepada masyarakat dengan program pendampingan ini diharapkan berkontribusi positif bagi peningkatan penjualan dan kapasitas produksi UMKM Jamu Herbal Asrifood, Carangwulung, Wonosalam Jombang, Jawa Timur dimana dimasa pandemi ini jamu herbal dari rimpang dan rempah diminati masyarakat Indonesia karena khasiatnya dalam meningkatkan imunitas tubuh.

Adapun target luaran yang akan dicapai adalah jurnal ilmiah ABDIMAS ALTRUIS: Jurnal Pengabdian Kepada Masyarakat, publikasi di media cetak dan online, peningkatan kapasitas penjualan dan produksi UMKM Jamu Herbal Asrifood, Carangwulung, Wonosalam Jombang, Jawa Timur.

Kata kunci : Digital Marketing, Penjualan, Produksi, UMKM Jamu Herbal Asrifood, Mesin Penggiling

\begin{abstract}
The main issue of community service today is the use of digital marketing to increase sales and production capacity of MSME Herbal Medicine Asrifood, Carangwulung, Wonosalam Jombang, East Java because the marketing system owned by MSMEs is not optimal, especially in the digital marketing field. some souvenir shops in the city of Jombang and e-commerce so that sales are not optimal.

Another problem faced by MSME Herbal Medicine Asrifood, Carangwulung, Wonosalam Jombang, East Java is that the production capacity of herbal herbal medicine is not optimal due to the problem of not having a flour processing machine or grinding machine and has been borrowing from neighbors. This inevitably results in the production process being hampered and not optimal in terms of time, effort, and cost. The results of community service with this mentoring program are expected to contribute positively to increasing sales and production capacity of MSME Herbal Herbal Asrifood, Carangwulung, Wonosalam Jombang, East Java
\end{abstract}




\section{JURNAL ABDIMAS

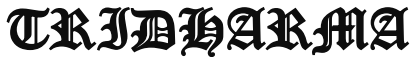 AHA}

P-ISSN 2615-6849, E-ISSN 2716-070X

Jurnal ABDIMAS Vol.3,No.1,Desember 2021,Hal(30-37)

@Prodi Manajemen Fakultas Ekonomi Universitas Pamulang

Email: abdimasjurnal.unpam@ gmail.com Telp: (021) 741-2566

where during this pandemic herbal herbal medicine from rhizomes and spices is in demand by the Indonesian people because of their properties in increasing body immunity.

The output targets to be achieved are the scientific journal ABDIMAS ALTRUIS: Journal of Community Service, publications in print and online media, increasing sales and production capacity of MSME Herbal Medicine Asrifood, Carangwulung, Wonosalam Jombang, East Java.

\section{Keywords: Digital Marketing, Sales, Production, UMKM Jamu Herbal Asrifood, Grinding Machine}

\section{PENDAHULUAN}

\subsection{Analisa Situasi}

Pandemi yang melanda Indonesia sejak Maret 2020 hingga saat ini membuat masyarakat memiliki kewaspadaan sendiri terhadap kebersihan diri dan kesehatan tubuh. Protokol kesehatan dijalankan sesuai dengan instruksi kesehatan dan pemerintah seperti memakai masker, mencuci tangan, dan jaga jarak minimal 1 meter. Masyarakatpun dihimbau untuk menjaga daya tahan tubuh dengan mengkonsumsi makanan sehat, dengan konsumsi sayur dan buah yang kaya vitamin, suplement vitamin maupun jamu herbal alami dari rimpang dan rempah seperti rimpang kunyit, temulawak, jahe dst serta rempah seperti ketumbar, sereh, daun salam dst.

Perubahan pola hidup masyarakat akibat pandemi tersebut membuat penjualan supplement vitamin maupun jamu herbal semakin meningkat terlebih jamu herbal instan karena masyarakat tidak perlu bersusah payah membuat jamu sendiri dirumah. Jamu herbal umunya dikemas dalam bentuk cair dan bubuk. Pengemasan dalam bentuk cair memiliki kelemahan masa expired yang lebih pendek sekitar 3 hari dan sulit dikirim keluar kota karena keterbatasan ekspedisi namun jamu dalam bentuk serbuk dengan kualitas sama mampu mengatasi hambatan tersebut. Jamu dalam bentuk serbuk mudah dibawa, dapat dikirim ke luar kota dengan mudah, dan memiliki umur kadaluarsa yang lebih panjang.

Salah satu daerah penghasil rempah dan rimpang di Jawa Timur yaitu
Wonosalam, Jombang yang merupakan daerah pegunungan yang memiliki hasil pertanian dan perkebunan yang melimpah seperti rimpang dan rempah. Umumnya hasil pertanian tersebut di jual langsung dengan harga yang relative sangat murah disebabkan oleh ulah para tengkulak yang mempermainkan harga, sehingga terkadang masyarakat merasa dirugikan dari penjualan tersebut olehkarena itu muncullah beberapa UMKM yang mengolah hasil panen menjadi barang jadi atau setengah jadi untuk meningkatkan nilai jual rimpang dan rempah salah satunya UMKM CV Asrifood dengan merek dagang "ASRIFOOD ".

Tabel. 1.1 Profil UMKM

\begin{tabular}{|l|l|l|}
\hline NO & \multicolumn{1}{|c|}{ Jenis } & \multicolumn{1}{|c|}{ Keterangan } \\
\hline 1. & Nama Usaha & UD Asrifood \\
\hline 2. & Alamat Usaha & $\begin{array}{l}\text { Dusun Segunung } \\
\text { RT/RW 02/04, } \\
\text { Carangwulung, } \\
\text { Wonosalam, } \\
\text { Jombang, Jawa } \\
\text { Timur }\end{array}$ \\
\hline 3. & Pemilik & $\begin{array}{l}\text { Ani Muslimah, } \\
\text { S.Pd }\end{array}$ \\
\hline 4. & Tahun Berdiri & 2017 \\
\hline 5. & No tlp & 081232830383 \\
\hline 6. & Bidang Usaha & $\begin{array}{l}\text { Jamu Herbal } \\
\text { Instan bubuk }\end{array}$ \\
\hline 7. & $\begin{array}{l}\text { Jumlah } \\
\text { Karyawan }\end{array}$ & $\begin{array}{l}\text { orang } \\
8120314161241 \\
9\end{array}$ \\
\hline 8. & NIB & $\begin{array}{l}5123517020009- \\
23 \text { Berlaku sd } \\
10 / 12 / 2023\end{array}$ \\
\hline 9. & P-IRT \\
\hline
\end{tabular}




\section{JURNAL ABDIMAS

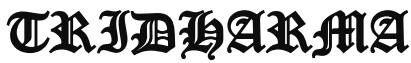 AIA}

P-ISSN 2615-6849, E-ISSN 2716-070X

Jurnal ABDIMAS Vol.3,No.1,Desember 2021,Hal(30-37)

@ Prodi Manajemen Fakultas Ekonomi Universitas Pamulang

Email: abdimasjurnal.unpam@gmail.com Telp: (021) 741-2566

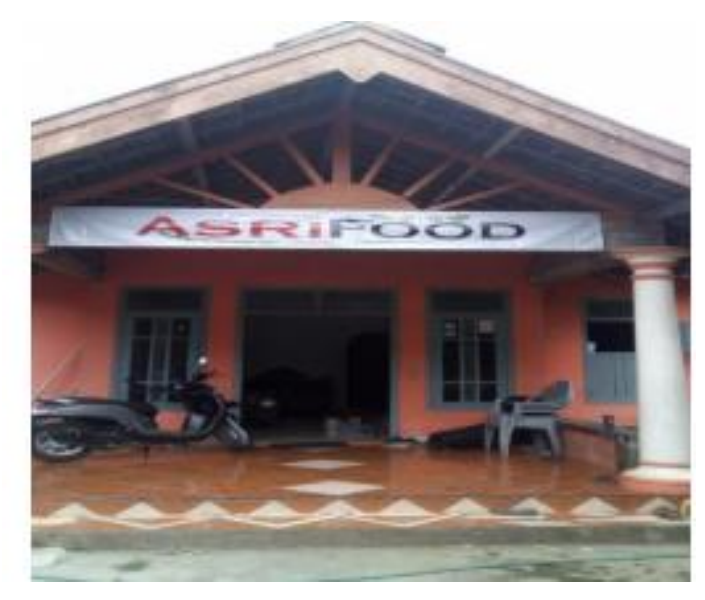

Gambar 1.1 Rumah Produksi UMKM Asrifood

\subsubsection{Proses Produksi}

UMKM Asrifood mampu memproduksi produksi $10 \mathrm{~kg} / \mathrm{hari}=$ 100 pack dengan harga Rp. 10.000,/pc dan laba Rp. 4000,-/pc. $80 \%$ memproduksi jamu + gula dan hanya $20 \%$ untuk produksi jamu non gula karena keterbatasan produksi yaitu menghaluskan rempah dengan blender kecil kapasitas rumah tangga seharusnya menggunakan mesin pembuat tepung/penggiling rempah padahal permintaan jamu non gula tinggi karena dinilai lebih sehat dan kalori rendah sehingga aman untuk penderita diabetes dan konsumen yang sedang diet.

Kegiatan produksi pengolahan bahan baku rimpang dan rempah menjadi serbuh minuman instan membutuhkan beberapa alat dan bahan seperti pada tabel.

Tabel 1.1. Tabememl alat dan bahan Pembuatan minuman serbut jamu herbal

\begin{tabular}{|l|l|}
\hline \multicolumn{2}{|c|}{ instan } \\
\hline Bahan : & Alat \\
Jahe emprit & Timbangan Mesin Baskom \\
Temu Lawak & Sealer \\
Kunyit kuning & Alat asak(Kompor,Panci \\
Kunyit Putih & susun dan wajan) \\
Gula Pasir & Plastik Kemasan \\
& Mesin Parut \\
\hline
\end{tabular}

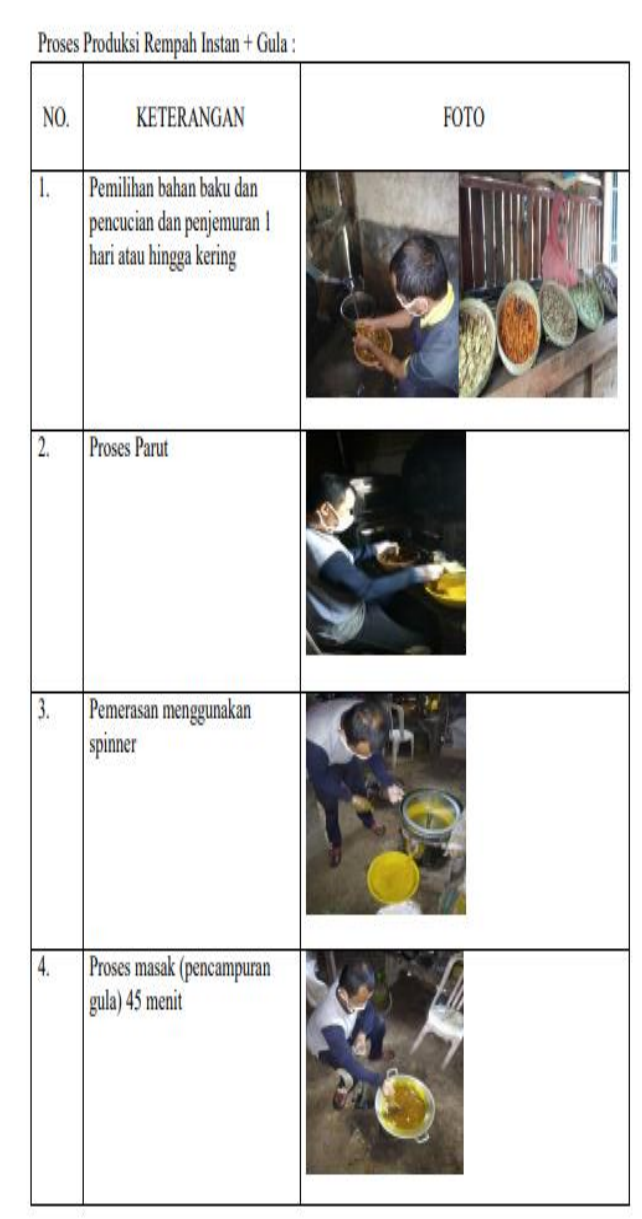

Proses Produksi Rempah Instan Tanpa Gula :

\begin{tabular}{|l|l|l|}
\hline N0. & \multicolumn{2}{|c|}{ KETERANGAN } \\
\hline 1. & $\begin{array}{l}\text { Pemilihan bahan baku, } \\
\text { pencucian, penjemuran }\end{array}$ & 2.Proses 0ven \\
\hline 3. & $\begin{array}{l}\text { Pengilingan bahan baku } \\
\text { (mengguanakan blender } \\
\text { kapasitas rumah tangga ) atau } \\
\text { pinjam tetangga }\end{array}$ & 4.Pengemasan \\
\hline 5. & $\begin{array}{l}\text { Produk Jamu Herbal Serbuk } \\
\text { Asrifood }\end{array}$ & fon \\
\hline
\end{tabular}

1.1.2 Pemasaran

Pemasaran yang dilakukan UMKM Asrifood selama ini dengan 


\section{JURNAL ABDIMAS

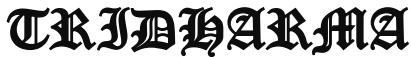

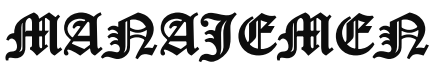

sistem konsinyasi di beberapa outlet/toko oleh-oleh khas Jombang. Menurut Maria (2011:16) sistem konsinyasi adalah pihak yang memiliki barang menitipkan barangnya kepada pihak lain untuk dijualkan dengan adanya perjanjian tertentu.

Selain sistem konsinyasi penjualan juga dilakukan $\mathrm{d}$ ecommerce shopee namun penjualan tidak lebih besar dari sistem konsinyasi. Pemasaran di media sosial, emggunakan website jiga belum diupayakan oleh UMKM ini karena keterbatasan sumberdaya dan dana pemasaran.

Penjualan perbulan sebelum pandemi sebanyak kurang lebih $1000 \mathrm{pc} / \mathrm{bln}$ jamu plus gula dan non gula dan saat pandemi meningkat menjadi $2500 \mathrm{pc} / \mathrm{bln}$ terlebih untuk jamu non gula bahkan bisa lebih jika pemasaran diperluas dengan sistem website dan media sosial namun dikarenakan kemampuan produksi yang terbatas untuk jamu non gula karena tidak memiliki mesin pembuat tepung/penggiling maka UMKM hanya mampu memproduksi jamu non gula $30 \%$ saja.

\section{RUMUSAN MASALAH}

Berdasarkan analisis situasi permasalahan di atas, maka tersusunlah rumusan masalah dalam kegiatan PKM ini, sebagai berikut :

a. Sistem pemasaran yang kurang luas yang hanya menggandalkan sistem konsinyasi di toko oleh-oleh khas Jombang (utamanya) mengakibatkan penjualan tidak maksimal karena peluang usaha jamu ini sangat besar terlebih di masa pandemi ini.

b. Tidak adanya mesin pengolah tepung/penggiling rempah setelah proses oven menyebabkan UMKM tidak bisa memproduksi jamu non gula dalam kapasitas besar padahal permintaan jamu non gula sama dengan permintaan jamu plus gula yaitu 1500 pc/bulan. Selama ini UMKM menggunakan blender skala rumah tangga dan meminjam mesin milik tetangga saat tidak terpakai sehingga proses produksi jamu non gula kurang optimal tidak efisien dan efektif.

\section{TUJUAN KEGIATAN}

Adapun tujuan yang hendak dicapai melalui kegiatan pengabdian kepada masyarakat, sebagai berikut :

a. Dapat membantu pelaku UMKM Asrifood dalam melakukan pemasaran produk melalui sosial media maupun ecommerce shopee sehingga market sharenya lebih luas

b. Membantu pelaku UMKM Asrifood untuk lebih produktif dengan memberikan mesin penggiling rempah yang bertujuan memudahkan proses produksi jamu instan serta lebih hemat waktu.

\section{TINJAUAN PUSTAKA \\ Digital Marketing}

Pengertian digital marketing dalam perspektif seorang pengusaha atau pebisnis lebih kepada sistem pemasaran dengan menggunakan media internet. Sudah pasti, di dalamnya termasuk mobile phone hingga beberapa situs jejaring sosial lainnya. Hanya saja, agar Teknik ini lebih mengena kepada sasaran, sepertinya Teknik promosi lebih dikesampingkan dan mengutamakan komunikasi. Menjalin hubungan secara personal dengan konsumen dengan cara mendengar keluhan atau saran akan membuat pelanggan lebih merasa dihargai. Yang pada akhirnya akan memberikan nilai tambah terhadap perkembangan bisnis terutama brand perusahaan. Terlihat sederhana namun sulit untuk dipastikan terlebih bagi mereka yang kurang memahami akan pengertian digital marketing sebenarnya. (Daengs, Achmad, Andi Farouq, 2016 : 287-293). Menurut Urban (2004:2) Digital Marketing menggunakan internet dan teknologi informasi untuk memperluas dan meningkatkan fungsi marketing tradisional. 


\section{JURNAL ABDIMAS

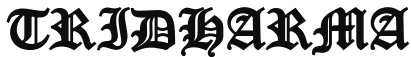 AHA}

P-ISSN 2615-6849, E-ISSN 2716-070X

Jurnal ABDIMAS Vol.3,No.1,Desember 2021,Hal(30-37)

@Prodi Manajemen Fakultas Ekonomi Universitas Pamulang

Email: abdimasjurnal.unpam@ gmail.com Telp: (021) 741-2566
Definisi ini berkonsentrasi pada seluruh marketing tradisional. Kita juga dapat menyatakan bahwa pendapat seperti interactive marketing, one-toone marketing, dan e-marketing. Erat kaitannya dengan digital marketing. Mnurut Ridwan Sanjaya \& Joshua Tarigan (2009:47) adalah kegiatan marketing termasuk branding yang menggunakan berbagai media berbasis web seperti blog, web site, email, adwords, ataupun jejaring social. Tentu saja digital marketing bukan hanya berbicara tentang marketing internet. Adapun teori dari Digital Marketing, adalah : 1. Content Marketing (Pemasaran Konten) Content Marketing adalah sebuah cara menjangkau hubungan dan mempertahankan pelanggan lewat konten-konten yang berbasis kepentingan pelanggan. 2. Search Engine Marketing (Teknik Pemasaran Produk) Search Engine Marketing adalah sebuah cara mencari informasi produk melalui search engine atau mesin pencari dengan mengetikkan kata atau produk yang akan dibeli. 3. Social Media Strategy (Strategi Sosial Media) Social Media Strategy adalah sebuah cara memasarkan produk melalui media social, seperti blog, facebook, twitter, dan lain-lain. 4. Konsep Pull ( Menarik) Merupakan konsep yang menjelaskan bahwa konsumenlah yang aktif dalam pencarian informasi ataupun lainnya mengenai produk yang ingin dibelinya tersebut. 5. Konsep Push ( Dorong ) Merupakan konsep komunikasi yang dilakukan oleh pemasar kepada calon customer atau customer bisa melalui email, SMS atau RSS.(Lucyantoro \& Rachmansyah, n.d.)

\section{Penjualan}

Penjualan merupakan kegiatan yang dilakukan oleh penjual dalam menjual barang atau jasa dengan harapan akan memperoleh laba dari adanya transaksitransaksi tersebut dan penjualan dapat diartikan sebagai pengalihan atau pemindahan hak kepemilikan atas barang atau jasa dari pihak penjual ke pembeli.( Mulyadi, 2008) Penjualan adalah pendapatan lazim dalam perusahaan dan merupakan jumlah kotor yang dibebankan kepada pelanggan atas barang dan jasa

Dapat disimpulkan penjualan adalah pemindahan hak kepemilikan atas barang atau jasa yang yang dilakukan perusahaan sebagai usaha pokok. (Aprilia, 2015)

\section{Produksi}

Menurut Sofyan Assauri, produksi didefinisikan sebagai berikut: "Produksi adalah segala kegiatan dalam menciptakan dan menambah kegunaan (utility) sesuatu barang atau jasa, untuk kegiatan mana dibutuhkan faktor-faktor produksi dalam ilmu ekonomi berupa tanah, tenaga kerja, dan skill (organization, managerial, dan skills). Murti Sumarti dan Jhon Soeprihanto memberikan pengertian produksi sebagai berikut : Produksi adalah semua kegiatan dalam menciptakan atau menambah kegunaan barang atau jasa, dimana untuk kegiatan tersebut diperlukan faktor-faktor produksi.Produksi menurut para ahli ekonomi sebagai upaya menciptakan kekayaan melalui eksploitasi manusia terhadap sumber-sumber kekayaan lingkungan. Produksi adalah mengolah alam sehingga tercipta bentuk terbaik yang mampu memenuhi kemaslahatan manusia (muhammad Baqir Asshadr, Iqtishaduna), dari teori tersebut sangat diharamkan memproduksi sesuatu yang merusak akidah yang sahih dan akhlak yang utama, segala sesuatu yang melucuti identitas ummat, menggoncangkan nilai-nilai agama dan akhlak, menyibukkan pada hal-hal yang siasia dan menjauhkannya dari keseriusan, mendekatkan pada kebathilan, menjauhkan dari kebenaran, mendekatkan dunia dan menjauhkan akhirat, mengingginkan kekayaan, uang dan keuntungan semata.

\section{METODE PELAKSANAAN}

Pihak-pihak yang terlibat dalam kegiatan adalah Tim Program PKM C 19 UMSIDA yang terdiri dari dosen dan mahasiswa sebanyak 5 orang dan 2 orang dari UD Asrifood yang terdiri dari pemilik Usaha dan pegawai toko. Metode pelaksanaan program pengabdian kepada 


\section{JURNAL ABDIMAS

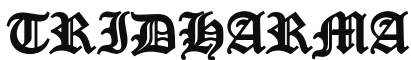 AIA}

P-ISSN 2615-6849, E-ISSN 2716-070X

Jurnal ABDIMAS Vol.3,No.1,Desember 2021,Hal(30-37)

@ Prodi Manajemen Fakultas Ekonomi Universitas Pamulang

Email: abdimasjurnal.unpam@ gmail.com Telp: (021) 741-2566 masyarakat UMSIDA COVID 19 (PKM C 19) UMKM Jamu Herbal Asrifood, Carangwulung, Wonosalam Jombang, Jawa Timur meliputi beberapa tahapan diantaranya:
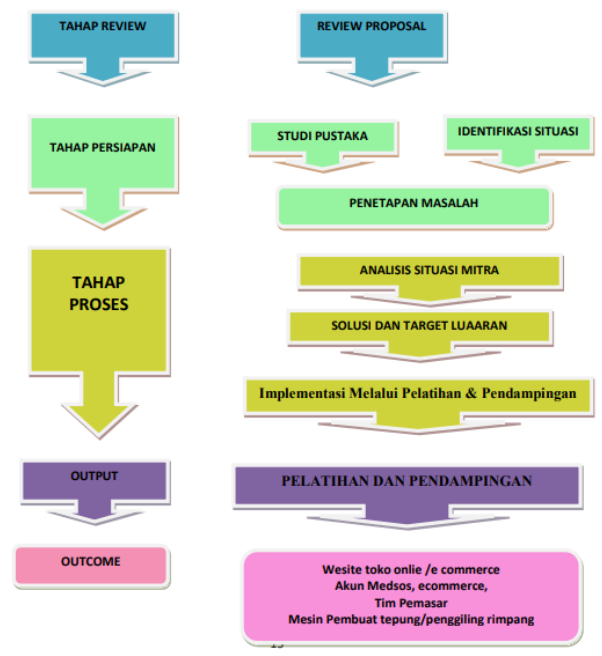

Deskripsi produk teknologi pemasaran yang akan di implementasikan pada UMKM Jamu Herbal Asrifood, Carangwulung, Wonosalam Jombang, Jawa Timur, pertama yaitu website ecommerce sebagai toko online. Pemasaran jamu herbal instan selama ini secara konsinyasi di toko oleh-oleh khas Sidoarjo dan Shopee saja sehingga pemasaran kurang optimal. Langkah kedua pemasaran online di beberapa ecommerce online marketplace di Indonesia dan media sosial karena selama ini ecommerce yang digunakan hanya Shopee dan whatsapp pribadi untuk media sosial secara intensif

\subsection{Tokopedia}

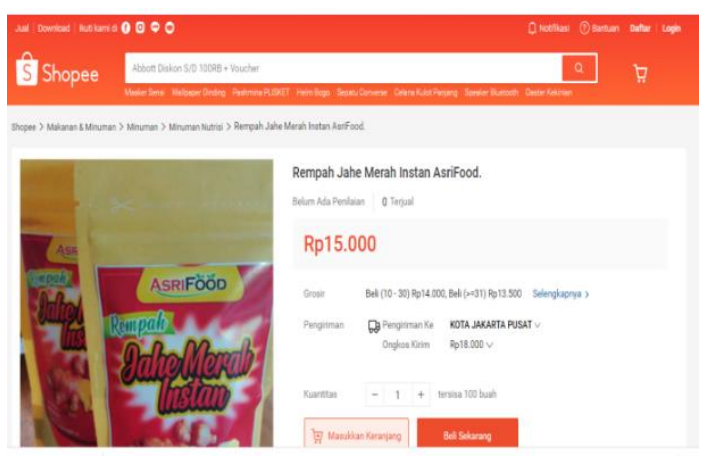

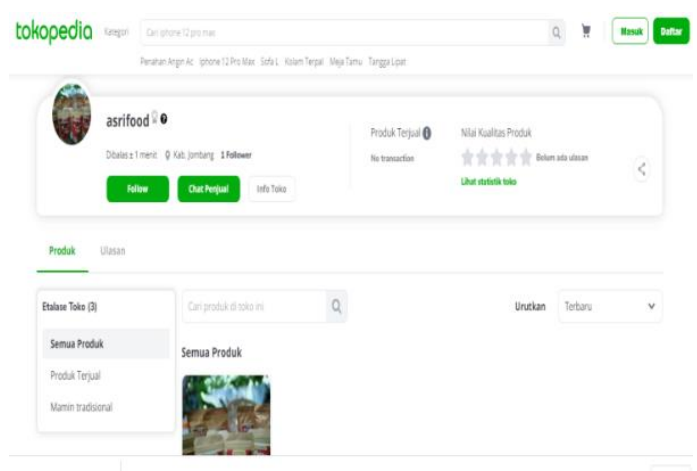

3.2. Shopee

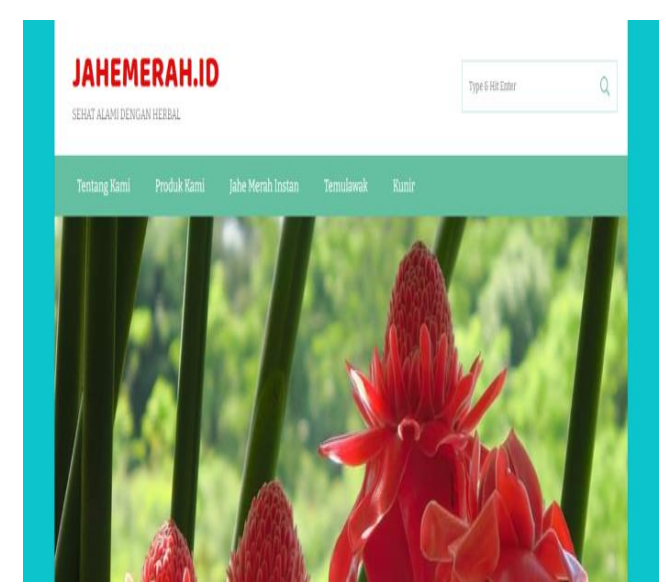

3.3. Web jahemeah.id

Tim pemasaran dari mahasiswa berjumlah 2 orang akan membantu pengaplikasian toko online, ecommerce marketplace dan media sosial kemudian memberikan pelatihan tentang pengaplikasian sistem tersebut pada pemilik dan 1 orang karyawan UMKM serta pendampingan agar sistem pemasaran dijalankan benar dan berkelanjutan. Deskripsi produk mesin produksi pertanian pembuatan tepung/penggiling rimpang yang akan membantu proses penggilingan rimpang setelah pengovenan kurang lebih 10 $\mathrm{kg} /$ hari untuk jamu non gula dan memiliki spesifikasi antara lain: tepung/penggiling rimpang yang akan membantu proses penggilingan rimpang setelah pengovenan kurang lebih $10 \mathrm{~kg} /$ hari untuk jamu non gula dan memiliki spesifikasi antara lain: 


\section{JURNAL ABDIMAS

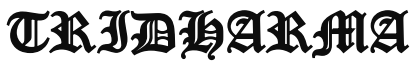 AIA}

P-ISSN 2615-6849, E-ISSN 2716-070X

Jurnal ABDIMAS Vol.3,No.1,Desember 2021,Hal(30-37)

@ Prodi Manajemen Fakultas Ekonomi Universitas Pamulang

Email: abdimasjurnal.unpam@gmail.com Telp: (021) 741-2566

Tabel. 3.1
\begin{tabular}{|l|l|}
\hline N0 & Keterangan \\
\hline 1 & Kapasitas : $500 \mathrm{gr}$ \\
\hline 2. & Power : 1.800 watl \\
\hline 3 & Voltage : $220-240 \mathrm{~V}$ \\
\hline 4 & Frekuensi : $50.60 \mathrm{hz}$ \\
\hline 5 & Rotation: $25.000 \mathrm{RM}$ \\
\hline 6 & Dimension: $23 * 19 * 37 \mathrm{~cm}$ \\
\hline
\end{tabular}

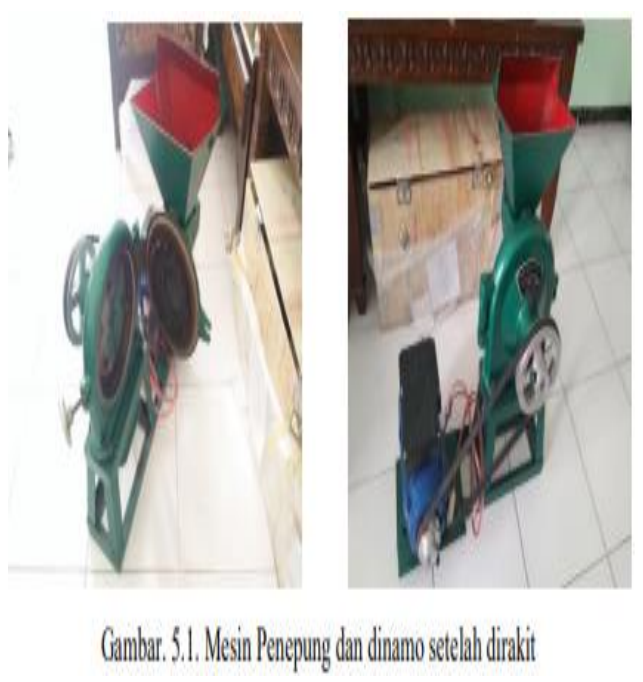

\section{HASIL DAN PEMBAHASAN \\ Hasil Kegiatan}

Dalam pelaksanaan kegiatan program Pengabdian Kepada Masyarakat UMSIDA COVID 19 (PKM C 19), hasil kegiatan yang telah dicapai adalah sebagai berikut: 1 . Hal pertama yang dilakukan oleh tim pelaksana adalah melakukan pertemuan awal yaitu interview mengenai permasalahan, peluang,dan kebutuhan sebagai solusi peningkatan kapasitas produksi dan penjualan dengan pengusaha UKM UD Asrifood yaitu Ibu Ani Muslimah, S.Pd. dan suami, Bpk Yanto di rumah sekaligus tempat pembuatan produk jamu herbal instan bubuk yang beralamat di Dusun Segunung RT/RW 02/04, Carangwulung, Wonosalam, Jombang, Jawa Timur yang. 2. Selanjutnya tim pelaksana melakukan workshop penyusunan kebutuhan mesin penggiling/penepung rimpang dan design website online shop untuk pemasaran yang lebih luas yaitu seluruh wilayah Indonesia. 3. Pembelian mesin dan perakitan mesin penepung dan dinamo di Lab Teknik Mesin Umsida serta pembelian domain dan pembuatan website, pembuatan akun di ecommerce shopee, tokopedia.

1. Penyerahan Mesin Penepung Rimpang pada UD Asrifood tgl 31 Maret 2021 bertepatan di tempat produksi sekaligus toko UD Asrifood
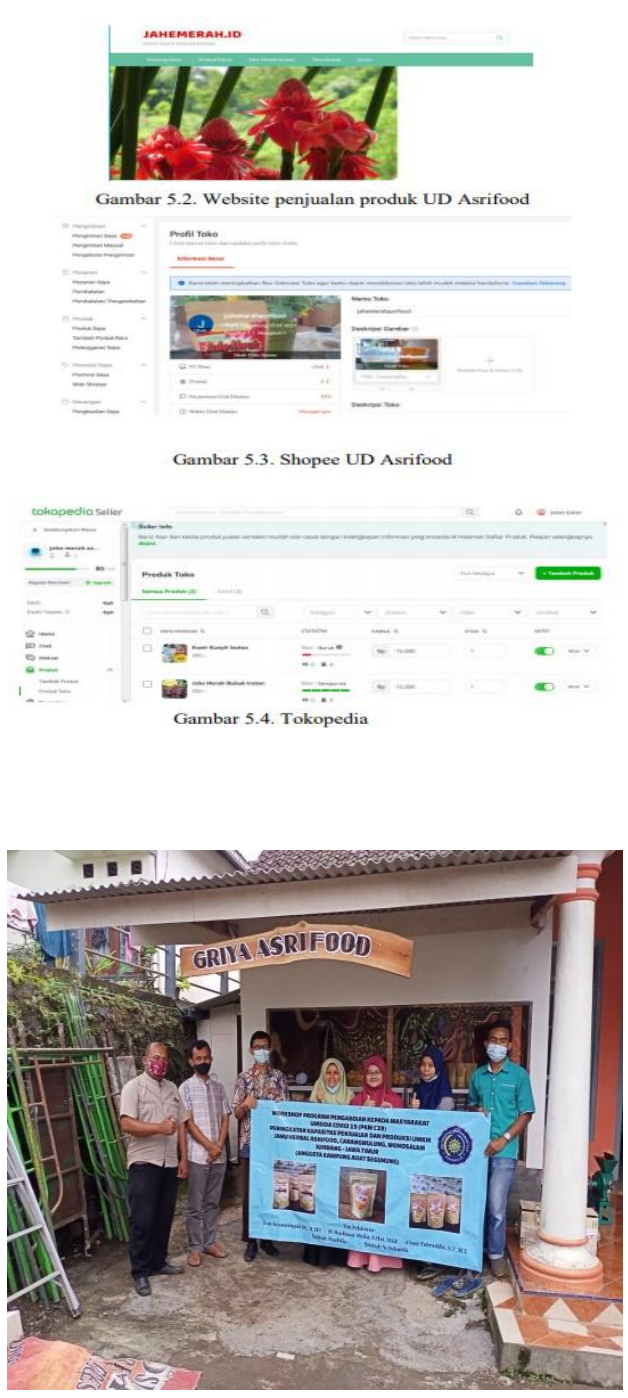

5.5. Peyerahan Mesin Penepung 


\section{JURNAL ABDIMAS

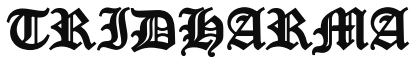 AtA}

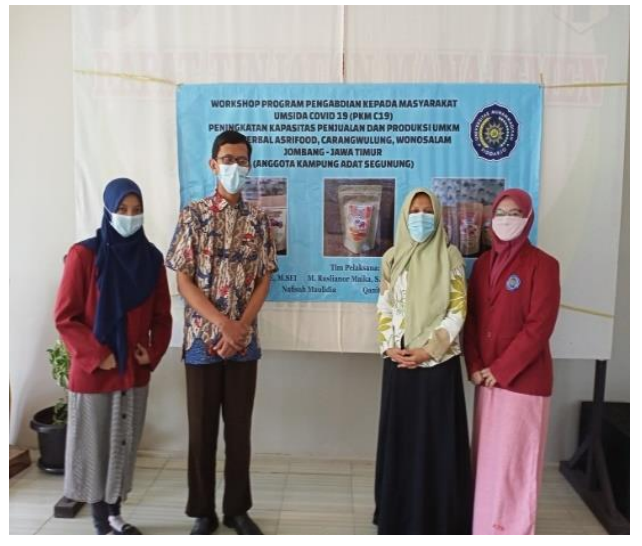

5.6. Sosialisasi Web, medsos \& e commerce di D Durian Park

\section{Luaran yang dicapai:}

Berikut adalah luaran yang dicapai dari kegiatan pengabdian masyarakat program kemitraan masyarakat Covid 19 (PKMC) Peningkatan Kapasitas Penjualan dan Produksi UMKM Jamu Herbal Asrifood, Carangwulung, Wonosalam Jombang, Jawa Timur, antara lain:

a. Peningkatan pemahaman pengusaha UMKM tentang penjualan online via website, e commerce, dan instagram.

b. Peningkatan pemahaman pengusaha UMKM tentang pentingnya pembentukan tim pemasaran oleh mahasiswa dalam pengaplikasian, pelatihan dan pendampingan toko online, ecommerce, dan medsos.

c. Peningkatan kapasitas dan efisiensi produksi dengan adanya mesin penepung rimpang.

\section{KESIMPULAN DAN SARAN \\ Kesimpulan}

Kegiatan pengabdian masyarakat program kemitraan masyarakat Covid (PKMC) Covid 19 (PKMC) Peningkatan Kapasitas Penjualan dan Produksi UMKM Jamu Herbal Asrifood, Carangwulung, Wonosalam Jombang, Jawa Timur telah dilakukan dengan beberapa tahap yaitu kegiatan brainstorming, diskusi dan tanaya jawab mengenai permasalahan yang dihadapi pengusaha UMKM selama pandemi utamanya dan disimpulkan masalah utama ada pada sistem pemasaran/penjualan yang terbatas, pemahaman sistem pemasaran online berbasis website, e commerce, dan medsos yang kurang, kurangnya tim pemasar, teknologi untuk membantu peningkatan kapasitas produksi secara efektif dan efisien. Pemecahan solusi dilakukan dengan worksop penyusunan rencana pembuatan pemasaran online berbasis website, e commerce dan medsos, pembelian dan perakitan mesin penepung rimpang.

\section{Saran}

Keterbatasan ruang dan waktu bagi tim untuk sosialisasi dan pendampingan secara langsung saat pandemi Covid sehingga interaksi dengan pelaku UMKM dilakukan lebih banyak via zoom dan Video call whatsapp.

\section{DAFTAR PUSTAKA}

Afrida, Yenti. "APLIKASI PENETAPAN DISKON DALAM PELUNASAN MURABAHAH DI PERBANKAN SYARIAH” 25 (2015): 23.

Almunawwaroh, Medina, and Rina Marliana. "ANALISIS PENGARUH PEMBIAYAAN MUSYARAKAH TERHADAP PROFITABILITAS BANK SYARIAH DI INDONESIA" 12 (2017): 14.

Ansori, Aan. "PENERAPAN E-BANKING
SYARIAH
PADA
SISTEM
INFORMASI MANAJEMEN
PERBANKAN SYARIAH." Banque

Syar'i : Jurnal llmiah Perbankan Syariah 3, no. 1 (July 6, 2019): 113. Faizal, Moh. "SYIRKAH PRINSIP BAGI HASIL PADA PEMBIAYAAN DIBANK SYARI'AH," n.d., 24.

Fitriyani, Ika, Nining Sudiyarti, and M Nur Fietroh. "STRATEGI MANAJEMEN BISNIS PASCA PANDEMI COVID- 


\section{JURNAL ABDIMAS

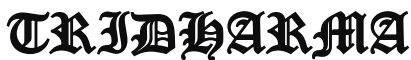 AIA}

P-ISSN 2615-6849, E-ISSN 2716-070X

Jurnal ABDIMAS Vol.3,No.1,Desember 2021,Hal(30-37)

@Prodi Manajemen Fakultas Ekonomi Universitas Pamulang

Email: abdimasjurnal.unpam@gmail.com Telp: (021) 741-2566
19," n.d., 9.

Harmoko, Irfan. "STRATEGI PEMASARAN PRODUK BANK SYARIAH DALAM PERSAINGAN BISNIS PERBANKAN NASIONAL," 2017,20.

Kholid, Muamar Nur, and Arief Bachtiar. "Pengaruh Dana Syirkah Temporer dan Good Corporate Governance terhadap Kinerja Maqasid Syariah Bank Syariah di Indonesia," n.d., 25.

Marlina, Asti, and Widhi Ariyo Bimo. "Digitalisasasi Bank Terhadap Peningkatan Pelayanan Dan Kepuasan Nasabah Bank." INOVATOR 7, no. 1 (October 29, 2018): 14.

Musri, Mustabsyirah, and Ali Rama. "ANALISIS PERILAKU DEPOSAN PERBANKAN DI INDONESIA (STUDI KASUS BANK SYARIAHDAN KONVENSIONAL)" 1, no. 1 (2015): 34.

Panduan_Penyelenggaraan_Digital_Branch DPNP_FINAL (FIX).Pdf," n.d. Salam, Muhammad Aminul Khoiris. "PERILAKU PRODUKSI DI TENGAH

\section{KRISIS GLOBAL AKIBAT PANDEMI COVID-19 DAN MEMANFAATKAN MEDIA ONLINE FACEBOOK SEBAGAIALTERNATIF PASAR," n.d., 22.}

Vebiana, Vera. "Perbankan Digital , Pengalaman Pelanggan, dan Kinerja Keuangan Bank Syariah," n.d., 5.

Pasaribu, V. L. D., Priadi, A., Anismadiyah, V., Rahayu, S., \& Maduningtias, L. (2021). PENYULUHAN KREATIF DAN INOVATIF MENINGKATKAN MUTU PRODUKSI UMKM DI DESA

\author{
BELEGA \\ KABUPATEN \\ GIANYAR. Pro Bono Jurnal \\ Pengabdian Kepada \\ Masyarakat, 1(02).
}

Wibowo, Dimas Hendika, and Zainul Arifin. "ANALISIS STRATEGI PEMASARAN UNTUK MENINGKATKAN DAYA SAING," n.d., 8. 